\title{
Relating Equanimity to Mindfulness
}

\author{
Bhikkhu Anālayo ${ }^{1}$
}

Accepted: 14 June 2021 / Published online: 24 September 2021

(c) The Author(s) 2021

\begin{abstract}
A recent surge of interest in equanimity as an important and transformative dimension of the cultivation of mindfulness can benefit from discerning different types of equanimity recognized in the Buddhist traditions, such as between equanimity as a divine abode or immeasurable and equanimity as the absence of compulsive reactivity by way of likes and dislikes. In order to provide an early Buddhist background to a more fine-grained understanding of the construct of equanimity, the present article surveys key passages on equanimity in their relationship to mindfulness.
\end{abstract}

Keywords Divine abodes $\cdot$ Equanimity $\cdot$ Establishments of mindfulness $\cdot$ Immeasurables $\cdot$ Neutral feeling tone

Nonjudgment $\cdot$ satipațthāna $\cdot$ upekkhā $\cdot$ upekșā

According to a much-quoted operational working definition provided by Kabat-Zinn (1994, p. 4), mindfulness involves "paying attention in a particular way: on purpose, in the present moment, and nonjudgmentally." As clarified by Kabat-Zinn (2011, p. 291), the last of these qualifications "does not mean to imply to the novice meditator that there is some ideal state where judgments no longer arise ... but that we do not have to judge or evaluate or react to any of what arises, other than perhaps recognizing it in the moment of arising as pleasant, unpleasant, or neutral." In other words, the qualification nonjudgmental is not meant to deny that in the instructions in the Satipațthāna-sutta and its parallels the cultivation of mindfulness serves "to develop a clear understanding of the experience" (Dreyfus 2011, p. 48), but rather concerns the absence of judgmental reactivity as another component of the same type of mindfulness practice. On this understanding, the quality of being nonjudgmental can be related to an important dimension of the early Buddhist description on how to cultivate each of the four establishments of mindfulness, which should be undertaken in the following manner:

Being diligent, clearly knowing, and mindful, removing greed and sadness in the world.

(SN 52.6: ātāpl̄ sampajāno satimā, vineyya loke abhijjhādomanassam).

\section{Bhikkhu Anālayo}

1 Barre Center for Buddhist Studies, 149 Lockwood Road, Barre, MA 01005, USA
Being with diligent effort, right mindfulness, and right knowing, overcoming greed and sadness in the world. (SĀ 537: 精勤方便, 正念, 正知, 調伏世間貪憂).

The last part in the above description refers to the removal or the overcoming of greed and sadness (abhijjädomanas salabhidhyādaurmanasya/頜憂/brnab sems dang yid mi $b d e b a$ ), which can be understood as a counterpart to the notion of mindfulness as nonjudgmental (Anālayo 2019a). The suggested correlation would thereby highlight a basic dimension of mindfulness practice in the establishment of equanimity (upekkhä/upekșa/f涻/btang snyoms), which in the present context stands for the ability to remain equipoised with whatever arises, without giving in to immediate evaluations and reactions under the influence of likes and dislikes.

\section{Conceptualizations of Equanimity in Current Research}

The relationship of equanimity to mindfulness has received increasing attention in recent times, leading to a range of interesting conceptualizations of equanimity and related suggestions. A relationship to the absence of greed and sadness (representative of aversion), thematized in the passage translated above, emerges in a comment by Zeng et al. (2015a, 406), made specifically in the context of researching the Goenka vipassana meditation (on which see also Zeng et al. 2015b): "Equanimity refers to a peaceful attitude ... feeling neither greed regarding good feelings nor hatred toward bad feelings." 
As proposed by Desbordes et al. (2015, p. 356), equanimity "can be defined as an even-minded mental state or dispositional tendency toward all experiences or objects, regardless of their origin or their affective valence (pleasant, unpleasant, or neutral)." In this way, "a primary 'signature' of equanimity is in the temporal domain, in the form of a more rapid disengagement from initial emotional response and faster return to baseline" (p. 363).

As a result, as explained by Shoham et al. (2018, p. 704), "in an equanimous state, wanting or not wanting are determined by values, long-term goals, or prosocial intentions rather than [just] the hedonic tone of experience." Being in this condition comes about, in the words of Hadash et al. (2016, p. 1215), through the "cultivation of an intentional attitude of acceptance toward every sort of experience (pleasant or unpleasant, current or anticipated)." Commenting on the role of equanimity as a form of decentring in particular, Lomas et al. (2015, p. 100) reasoned that the cultivation of mindfulness "appears to facilitate a stance of decentring ... which means practitioners not only develop better awareness of their emotions, but also and crucially, greater tolerance of them." Moreover, Chan et al. (2014, p. 293) noted that equanimity "is first and foremost characterized by ... resilience in face of challenges ... [which] translates somatically to a heightened level of bodily vitality, and a capacity of acute awareness." Juneau et al. (2019, p. 3) explained that, "in stressful situations, equanimity makes it possible for a person to remain calm and to make decisions and follow behaviors that are the least contaminated by stress and arousal as possible." Juneau et al. (2021, p. 10) reasoned that mindfulness practices "may lead to a de-automatisation of the relationship between stimuli and affective evaluations ... This de-automatisation of emotional processing could lead to more neutral reactions to emotional stimuli - or in other words, to equanimity." In fact, research by Juneau et al. (2020, p. 1809) found that "the more experience participants had in the practice of mindfulness, the higher their equanimity scores."

Exploring the relationship between equanimity and mindfulness practices has led to the proposal that insight and equanimity are key effects of mindfulness meditation (Eberth et al. 2019). It has even been proposed that "mindfulness skills develop as a function of equanimity" (Rogers et al. 2021, p. 108), which could perhaps be understood to convey that the cultivation of mindfulness matures concomitant with the growth of equanimity. In other words, the cultivation of mindfulness and equanimity could be visualized as involving a dynamic interrelationship, where each of these two constructs supports and enhances the other.

\section{Types of Equanimity}

As a reference point for further research on the interrelationship between equanimity and mindfulness, it could be advantageous to note that Buddhist usage recognizes different types of equanimity (Anālayo 2008). The need to take into consideration such differentiations can be illustrated with the example of the reasoning proposed by Weber (2017, p. 151):

The question arises whether the majority of current mindfulness measurement merely represent attention or memory scales rather than reflect the deeper and more profound depth of the practice. In Buddhism, Mindfulness is a key part of developing compassion in self and others ... when unpleasant thoughts arise, an individual is able to attend to them without denial, repression or aversion. Similarly, when pleasant thoughts arise, one is able to attend to these without becoming over-excited or trying to prolong these, or becoming addicted to them. In Tibetan Buddhism this inner cultivation of equanimity is referred to as the Hinayana attitude, and that the Mahayana attitude is then cultivated when this attitude is extended towards all beings (friends, enemies, and strangers).

Before turning to the need of differentiating equanimity constructs, it could be noted that self-compassion, at least as a stand-alone practice, is a rather recent development (Anālayo \& Dhammadinnā 2021). Moreover, the use of the term Hīnayāna is unfortunate, as this is a derogatory term resulting from Buddhist polemical discourse which lacks historical reality. Throughout the history of Buddhism, there has not been an institution or religious group that could justifiably be called Hīnayāna (Anālayo 2014b). For this reason, it would be preferable to avoid using this term in scholarly writings in a way that gives the misleading impression that it refers to a real historical entity or actually existing Buddhist tradition.

The main problem, however, is that the above extract does not distinguish between equanimity as a divine abode or immeasurable state and equanimity as a dimension of the four establishments of mindfulness. These types of equanimity are not the same. This distinction is not about internally and externally directed equanimity, as assumed by Weber and Lowe (2021, p. 685): "from the Theravada perspective, this attitude manifests as an internal reaction to one's own attachment, aversion and indifference ... Mahayana Buddhism still incorporates this viewpoint, but then externalizes this onto friends, enemies and strangers." The Theravāda notion of equanimity as a divine abode or immeasurable involves others as well and is not just about one's own internal reactions (Vism 317). But the 
idea of having equanimity toward "friends, enemies and strangers" concerns equanimity as a divine abode or immeasurable. This needs to be differentiated from the equanimity that forms part of the cultivation of the establishments of mindfulness or of mindfulness-based practices in clinical usage.

Drawing this distinction is not meant to propose that these two types of equanimity could not be related to each other in some way. As shown by Pagis $(2015$, p. 39), even in the context of an intensive insight meditation retreat, "meditation-based equanimity is not only a psychological state but also a social attitude." From an early Buddhist perspective, the external dimension of mindfulness naturally leads over to mettā and compassion (SN 47.19, SĀ 619, and T 1448; Anālayo 2019d). Nevertheless, the meditative cultivation of the divine abodes or immeasurables differs from the meditative cultivation of the four establishments of mindfulness. Each of these forms of practice relates to a distinct construct of equanimity.

From the perspective of drawing this distinction, it becomes less surprising if studies of mindfulness in clinical health seldom identify "equanimity" as a key facet (Weber 2021). This may simply be because the type of equanimity that is directly relevant to such research has already been captured with the notions of non-judgment and acceptance.

In addition to the two types of equanimity already mentioned, for the purpose of surveying relevant material from early Buddhist texts a third type could be added, namely equanimity in the form of neutral feeling tone. In this way, three chief types of equanimity can be distinguished, whose connotations could be captured by adding the following qualifications:

Equanimity as hedonic neutrality (a feeling tone)

Equanimity as interpersonal impartiality (a divine abode or immeasurable state)

Equanimity as equipoise (a state of mental balance)

Equanimity as hedonic neutrality stands in place of what the early discourses more usually refer to as a feeling tone that is literally "neither-unpleasant-nor-pleasant" (Anālayo 2017). An example can be found in a fivefold analysis applied to the hedonically felt dimensions of experience, which distinguishes between what is bodily pleasant or unpleasant, what is mentally agreeable or disagreeable, and as its fifth item that which fits neither of these four categories. This fifth alternative, in the form of hedonic neutrality (bodily and mental), is termed "the faculty of equanimity" (DN 33: upekkhindriya, StacheRosen 1968, p. 153: upeksendriya; T 12: 捨受根; this particular set of five faculties is not mentioned in another parallel, DA 9). Another passage indicates that the type of equanimity under discussion here is not necessarily commendable in and of itself:

'I say that equanimity is also of two types: to be cultivated and not to be cultivated.' This being said, in relation to what is it said? Here, the equanimity of which one knows: 'On cultivating this equanimity, unwholesome states increase for me and wholesome states decrease,' such type of equanimity should not be cultivated. Here, the equanimity of which one knows: 'On cultivating this equanimity, unwholesome states decrease for me and wholesome states increase,' such type of equanimity should be cultivated.

(DN 21: upekkham p' āham ... duvidhena vadāmi sevitabbam pi asevitabbam pi ti, iti kho pan' etam vuttam, kiñ c'etam paticca vuttam? tattha yam jañ̃̃̄a upekkham: imam kho me upekkham sevato akusala dhammā abhivadḍanti, kusalā dhammā parihāyantī ti, evarūpā upekkhā na sevitabbā. tattha yam jañ̃̄a upekkham: imam kho me upekkham sevato akusalā dhammā parihāyanti, kusalā dhammā abhivadd hantī ti, evarūpā upekkhā sevitabbā).

That kind of equanimity which harms oneself, harms others, or harms both, this equanimity should have been relinquished. As to the equanimity which does not harm oneself, does not harm others, does not harm both, a monastic, being with collected mindfulness and without forgetfulness, knows the time for it.

(DĀ 14: 彼捨身者, 自害, 害他, 亦二俱害, 捨此捨 已. 如所捨, 不自害, 不害他, 二俱不害, 知時比丘專 念不忘; adopting the variant 捨已 instead of 身已).

Regarding equanimity, I say that there are also two sorts: that which should be undertaken and that which should not be undertaken. As to the equanimity that should not be undertaken, I discarded that immediately. As to the equanimity that should be undertaken, on account of knowing the right time for it, I therefore accomplished it with mindfulness and comprehension. (MĀ 134: 捨者, 我說亦有二種: 可行, 不可行. 若捨 不可行者, 我即斷彼. 若捨可行者, 我爲彼知時, 有 念, 有智, 成就彼故).

The kinds of equanimity ... have two meanings, namely, what should be undertaken and what should not be undertaken. The one that should be undertaken is reckoned to be all wholesome states; the one that should not be undertaken is reckoned to be all unwholesome states. (T 15: 捨身 ... 有其二義, 謂可行, 不可行. 可行者, 謂諸善法; 不可行者, 謂諸不善法). 
Although the formulations in the parallels differ, the proposals made in each can be seen to involve the same fundamental ethical distinction: Types of equanimity that foster an increase in what is unwholesome (in terms of being harmful to oneself or others) should not be cultivated, as to do so is only appropriate for types of equanimity that foster an increase in what is wholesome. The parallels apply the same basic distinction also to types of pleasure and displeasure. Complementing these, the equanimity under discussion clearly corresponds to hedonic neutrality.

In this way, the key point is not to opt invariably for such neutrality as the supreme option, but much rather to monitor the repercussions of this type of equanimity. Such monitoring would be a task requiring mindfulness. If the way one cultivates equanimity as hedonic neutrality has detrimental results, if it in some way causes harm for oneself or others, it needs to be recognized with mindfulness as being unwholesome and for this reason should not be encouraged.

When viewed from the perspective of the four establishments of mindfulness, equanimity as hedonic neutrality relates in particular to the second of the four establishments. According to the Satipatthāna-sutta and its two Chinese parallels, the task of mindful contemplation here is to recognize the experience of neutral feeling tones (= equanimity as hedonic neutrality) and to discern between worldly and unworldly manifestations of these neutral feeling tones. This distinction can be taken to match the division proposed in the passages translated above between what is commendable and what is not commendable. In this way, the first of the three types of equanimity distinguished above relates to only one of the establishments of mindfulness; it is not relevant to the entire set of four.

The second type of equanimity, interpersonal impartiality, is the last of the four divine abodes or immeasurables. Its cultivation builds on and rounds off the previous practice of mettā, compassion, and sympathetic joy (Anālayo 2015). In conjunction, these four present ideal mental attitudes, in the sense of offering alternative and complementary ways of relating to others in a wholesome manner. Although here equanimity builds on the other three divine abodes or immeasurables, this does not imply that equanimity is necessarily superior to the other three. In fact, at times such equanimity may not be the appropriate choice, as a particular situation instead calls for compassion. An example to illustrate such a need involves the Buddha's attendant Ānanda, who was present when his senior monastic companion Sāriputta was publicly contradicted repeatedly by another monastic. After clarifying that the position taken by Sarriputta was correct and the one taken by the other monastic misguided, the Buddha turned to Ānanda to reprimand him for not intervening:
Ānanda, would you indeed look on with equanimity when a senior monastic is being harassed? Ānanda, will there indeed not even be compassion for a senior monastic who is being harassed?

(AN 5.166: atthi nāma, ānanda, theram bhikkhum vihesiyamānam ajjhupekkhissatha? na hi nāma, ānanda, kāruñ̃̃am pi bhavissati theramhi bhikkhumhi vihesiyamānamhī $t i$ ?).

A highly respected and virtuous elder monastic is being contradicted by another. For what reason did you indulge it and did not restrain [the other]? You are a deluded person, being equanimous, without kindheartedness, and turning your back on a highly respected and virtuous elder.

(MĀ 22: 上尊名德長老比丘爲他所詰. 汝何以故, 縱 而不撿? 汝愚癡人, 無有慈心, 捨, 背上尊名德長老).

Ānanda, are you even being equanimous in the face of senior monastics being very much oppressed? A saintly senior monastic is being oppressed and there is no compassion at all?

(Up 2038: kun dga' bo khyod kyang dge slong gnas brtan rnams la rnam par gtses pa btang snyoms su byed dam? skyes bu chen po dge slong gnas brtan gtses pa la snying rje yang ma skyes sam?).

The above passages convey that equanimity, in the sense of interpersonal impartiality toward others, also requires mindful monitoring in order to decide if a more appropriate way of dealing with a particular situation is perhaps rather by arousing compassion. In addition to this monitoring function of mindfulness, the meditative radiation of these four divine abodes or immeasurables can also rely on mindfulness (Anālayo 2019b), so that abiding in equanimity in the form of interpersonal impartiality as such has a natural relationship to mindfulness.

From the viewpoint of the four establishments of mindfulness, however, equanimity and the other divine abodes or immeasurables would fall under the third establishment, contemplation of mental states. Out of those mental states mentioned in the Satipatthāna-sutta and in its Chinese $\bar{A}$ gama parallels, the one particularly relevant here would be the mindful recognition of whether the mind has "become great" (mahaggata/有大/chen por gyur ba). Although this qualification as such has a broad compass, it can be taken to apply to the divine abodes or immeasurables in particular, as these are often qualified with the same term "become great" (Anālayo 2018, p. 137). In this way, equanimity as interpersonal impartiality relates to only one out of the four establishments of mindfulness, being in this respect similar 
to the case of equanimity as hedonic neutrality. Neither are relevant to the entire set of four.

\section{Beyond Attraction and Repulsion}

The third of the types of equanimity, mentioned above, stands for equipoise in relation to anything that may happen. This is the type of equanimity directly relevant to all four establishments of mindfulness, in the sense of not reacting by way of greed and sadness. The nuance of mental balance that emerges in this way can be explored in relation to three dimensions of early Buddhist meditation practice: the absence of reacting by way of attraction and repulsion toward what is experienced through the senses, the inner balance of absorption attainment, and the cultivation of a superb balance of the mind through the awakening factors.

Beginning with the first of these three, the inner balance of this type of equanimity in relation to what is experienced through the senses can be nurtured through what could perhaps be reckoned an intentional form of perceptual training to step out of ingrained evaluations. A Pāli discourse and its Chinese Āgama parallel describe such perceptual training as a form of practice that builds on the cultivation of the four establishments of mindfulness. A first step here is to intentionally look at what is usually seen as not being repulsive from the perspective of it being repulsive, and to view what is generally experienced as repulsive from the viewpoint of it not being repulsive. By in this way relativizing the evaluative input that tends to underlie ordinary perception, it becomes possible to wean the mind gradually from relying on such evaluations until eventually one remains simply equanimous:

[Having the aspiration:] "Avoiding both [the evaluations] 'unrepulsive' and 'repulsive,' may I dwell equanimous, mindful, and clearly knowing," one therein dwells equanimous, mindful, and clearly knowing.

(SN 52.1: appațikūlañ ca pațikūlañ ca tad ubhayam abhinivajjetvā upekkhako vihareyyam sato sampajāno ti, upekkhako tattha viharati sato sampajāno).

With an equanimous perception that [avoids] both repulsiveness and unrepulsiveness, one dwells with right mindfulness and right knowing.

(SĀ 536: 厭離不厭離俱, 捨想, 住正念正知).

By gradually weaning the mind from its ingrained evaluations in terms of repulsiveness and unrepulsiveness, representative of likes and dislikes, a state of inner balance can be reached. The presence of mindfulness and clear knowing shows that this is not an encouragement to ignore what is experienced, but much rather involves the ability to apperceive fully what is there but with the inner freedom of seeing it in alternative ways. This inner freedom of seeing alternative perspectives is an important contribution made by mindfulness, hence the description in the above passages builds on the four establishments of mindfulness. Through the systematic cultivation of mindfulness, it becomes possible to see the whole picture, in a way, rather than blend out whatever does not conform to one's initial evaluation. Even the beautiful has something ugly to it, and the ugly has some dimension of beauty. Being able to see that, rather than opt for unilateral evaluations, becomes possible through mindfulness.

According to early Buddhist soteriology, the state of equanimity described here becomes an established trait, which will no longer be lost, when full awakening has been accomplished. The freedom of an arahant, who has brought the path of mindful training to its perfection and become free from defilements, manifests in a superb degree of equanimity in the face of anything experienced. In the case of visual experiences, for example, this takes the following form:

Having seen a form with the eye, one is neither joyful nor sad, dwelling equanimous, mindful, and clearly knowing.

(AN 4.195: cakkhunā rūpam disvā n' eva sumano hoti na dummano; upekkhako viharati sato sampajāno).

Seeing a form with the eye, one is neither joyful nor sad, being equanimous and evenly unaffected, with right mindfulness and right knowing.

(MĀ 12: 眼見色, 不喜不憂, 捨求無爲, 正念正智).

The same applies to the other sense doors of the ear, nose, tongue, body, and mind, which in early Buddhist thought features as a sixth sense. Whatever happens at any of these sense doors, profound equanimity prevails over the tendency to be tossed around amidst the heights of joy and the lows of sadness. As already mentioned above, such equanimity is not a form of indifference by way of ignoring what is happening, but much rather a mental attitude endowed with clarity and freedom, endowed with the full presence of mindfulness and clear knowing.

A specific instance of this type of equanimity finds description in a Pāli discourse passage and its parallels, which take up the Buddha's attitude toward three possible situations that could occur when he gives a teaching. This description has a direct relationship to the four establishments of mindfulness, as the exposition of the Buddha's attitude is explicitly designated to be about three establishments of mindfulness. These are specific to the present context and do not correspond to the standard exposition of four establishments of mindfulness by way of contemplation of the body, feeling tones, mind, and dharmas. The three possible situations covered under the heading of three establishments 
of mindfulness are when either all disciples pay attention, or else none of them pays attention, or else only some pay attention and others do not. When faced with such situations, the Buddha remains equanimous and dwells with mindfulness and clear knowing (Anālayo 2011, pp. 785-787, 2013, pp. 240-243, and 2020a, pp. 232-235). This exemplifies a superb degree of accomplishment in cultivating freedom from greed and sadness, where even taking up the role of the teacher comes with a profound inner balance that will not be affected by any lack of attention paid by the disciples.

The above-described equanimity in relation to sense experience in daily life (or an inattentive audience) can be related to the contemplation of the sense-spheres described in the Satipatthāna-sutta and its Madhyama-āgama parallel. This part of the instruction begins by directing mindful understanding to the nature of a fetter arisen in dependence on a sense organ and its object, based on which practice proceeds as follows:

One knows how an unarisen fetter arises, one knows how an arisen fetter is removed, and one knows how a removed fetter does not arise in the future.

(MN 10: yathā ca anuppannassa samyojanassa uppādo hoti tañ ca pajānāti, yathā ca uppannassa samyyojanassa pahānam hoti tã̃ ca pajānāti, yathā ca pahīnassa samyojanassa āyatim anuppādo hoti tañ ca pajānāti).

Actually having a fetter internally, one knows, as it really is, that there is a fetter internally; actually not having a fetter internally, one knows, as it really is, that there is no fetter internally. One thus knows, as it really is, how an unarisen fetter arises internally; and thus knows, as it really is, how an internally arisen fetter ceases and does not arise again.

(MĀ 98: 內實有結, 知內有結如真; 內實無結, 知內 無結如真. 若未生內結而生者, 知如真, 若已生內結 滅不復生者, 知如真).

This shows that the task of mindfulness comprises times when a fetter is present, which in the present context stands for reactivity by way of likes and dislikes toward what is seen through the eye, heard through the ear, etc. The presence of such a fetter implies that equanimity had so far not been established. With sustained practice of the type of mindful contemplation described above, however, a state of equanimity can be reached, in that seeing, hearing, etc. no longer trigger mental bondage. This in turn implies that the scope of mindfulness here is broader than that of the type of equanimity under discussion, as the latter can be seen to emerge as an outcome of training in mindfulness.

The equanimity under discussion being an outcome of the mindfulness practice described above also marks a difference compared to the other types of equanimity surveyed earlier in their relationship to the four establishments of mindfulness. Equanimity as hedonic neutrality and as interpersonal impartiality can become objects of the second and third establishment of mindfulness. The present case, however, is not so much an object of mindfulness practice, as it is rather its result. Moreover, this result is relevant to all four establishments of mindfulness, as evident in the passage taken up at the outset of this exploration, according to which the removal or overcoming of greed and sadness is an integral dimension of each of the four establishments of mindfulness.

\section{Absorption}

The scope of equanimity as a form of equipoise in early Buddhist meditation goes beyond freedom from greed and sadness as a key ingredient of the practice of the four establishments of mindfulness, as it is also of relevance to the cultivation of the four absorptions recognized in early Buddhist thought. Equanimity in the form of equipoise finds explicit mention in the standard description of the third level of absorption, which proceeds as follows:

With the fading away of joy one dwells equanimous, mindful, and clearly knowing, experiencing happiness through the body and, being one whom noble ones designate as 'one who dwells happily, equanimous, and mindful,' one dwells having attained the third absorption.

(MN 27: pītiyā ca virāgā upekkhako ca viharati sato ca sampajāno, sukhañ ca kāyena pațisamvvedeti, yam tam ariyā ācikkhanti upekkhako satimā sukhavihārī ti tatiyam jhānam upasampajja viharati).

Secluded from desire for joy, dwelling equanimous and without seeking anything, with right mindfulness and right knowing, and experiencing happiness with the body, one dwells having attained and accomplished the third absorption, which is designated by noble ones as an abiding in a happy dwelling with the equanimity and mindfulness of noble ones.

$(\mathrm{MA}$ 146: 離喜欲, 捨無求遊, 正念正智而身覺樂, 謂 聖所說, 聖所捨, 念, 樂住, 室, 逮第三禪成就遊).

The reference at the outset of the description in both versions to the absence of joy relates to a characteristic of the second absorption that needs to be left behind in order to be able to attain the third: joy (pīti/prīti/喜/dga' $b a)$. Whereas the first absorption is characterized by the presence of joy born of seclusion and the second absorption by the presence of joy born of concentration, with the third absorption joy is left behind and only the more 
subtle happiness remains. Such a happy dwelling, so the above description indicates, is designated by noble ones as being characterized by the presence of equanimity and mindfulness.

According to a more detailed analysis of the mental qualities and factors of each absorption in a Pāli discourse that shows some signs of later development in line with evolving Abhidharma thought (Anālayo 2014a, pp. $100-110$ and 2020 b, pp. 25-30), equanimity and mindfulness are already present in the first and second absorptions (MN 111: sati upekkhā), Yet, neither of the two is mentioned explicitly in what in the early discourses function as the standard descriptions of the first and second absorptions (although mindfulness is at times mentioned; Anālayo 2019c). The perspectives that emerge in this way reflect somewhat differing concerns. The standard descriptions in the early discourses take up those characteristics of an absorption that appear to be most relevant for their cultivation; the Abhidharma-type of descriptions instead aim at providing as comprehensive a coverage as possible. Combining these two perspectives, the following emerges: Equanimity and mindfulness are to some extent required for any absorption to occur. However, their role in the actual experience of absorption becomes particularly noticeable and prominent once the third absorption has been achieved. The same continues to hold for the fourth absorption:

With the abandoning of happiness and the abandoning of pain, and with the previous disappearance of joy and displeasure, one dwells with neutrality and purity of mindfulness and equanimity, having attained the fourth absorption.

(MN 27: sukhassa ca pahānā dukkhassa ca pahānā pubbe va somanassadomanassānam atthaingamā adukkhamasukham upekkhāsatipārisuddhim catuttham jhānam upasampajja viharati.).

With the cessation of pleasure and the cessation of pain, and with the previous disappearance of joy and displeasure, one dwells with neutrality and purity of equanimity and mindfulness, having attained and accomplished the fourth absorption.

(MĀ 146: 彼樂滅, 苦滅, 喜憂本已滅, 不苦不樂, 捨 念清淨, 逮第四禪成就遊).

With the fourth absorption, equanimity and mindfulness reach a peak of purity. This presumably reflects the depth of concentration reached once even the subtle type of happiness (or 'pleasure') that characterizes the third absorption has been left behind. In this way, here equanimity in the form of equipoise during absorption attainment combines with the other type of equanimity discussed above, hedonic neutrality. That is, the superb absence of pleasure and pain reached at this juncture naturally correlates with equanimity. At the same time, however, equanimity as equipoise does not depend on such absence, otherwise it would not have been mentioned as a prominent quality in the third absorption.

Similar to the case of equanimity/equipoise in relation to the senses, the equanimity/equipoise discussed here also has a more restricted compass than mindfulness. Although both qualities are required for each of the four absorptions, mindfulness is already needed when preparing for absorption attainment. At that time, the hindrances to absorption need first to be overcome. This requires the monitoring ability of mindfulness, as explicitly described in the contemplation of the hindrances in the Satipatthanna-sutta and its Madhyama-ägama parallel. Such monitoring can be illustrated with an extract that covers the arising and presence of the hindrance of restlessness-and-worry:

If restlessness-and-worry is present within, one knows: 'restlessness-and-worry is present within me' ... and one knows how unarisen restlessness-and-worry arises. (MN 10: santam vā ajjhattam uddhaccakukkuccam, atthi me ajjhattam uddhaccakukkuccan ti pajānāti ... yathā ca anuppannassa uddhaccakukkuccassa uppādo hoti tañ ca pajānāti).

Actually having restlessness-and-worry within, one knows, as it really is, that there is restlessness-andworry ... and one knows, as it really is, how unarisen restlessness-and-worry arises.

(MĀ 98: 內實有調悔, 知有調悔如真 .... 若未生調 悔而生者, 知如真; the formulation is based on a supplementation, as the original is abbreviated)

This instruction refers to a situation when equanimity is absent, as the presence or arising of restlessness reflects an agitated state of mind. Yet, mindfulness is clearly present, performing the task of monitoring the condition of the mind when restlessness (or worry) arises and when it is present. Such monitoring is a continuous requirement all the way up to full awakening, as according to early Buddhist thought it is only with arahants that restlessness no longer has a scope to manifest (AN 10.13).

\section{Awakening Factors}

Of particular relevance to the cultivation of liberating insight, with the potential of leading to full awakening, are the seven awakening factors, the last of which is equanimity. A description of the gradual building up of these seven awakening factors one-by-one, based on the meditation practice of mindfulness of breathing, shows in what way 
the immediately preceding factor of concentration leads to equanimity:

One carefully looks on with equanimity at the mind that has become collected in this way. Ānanda, at a time when a monastic carefully looks on with equanimity at the mind that has become collected in this way, at that time the awakening factor of equanimity is aroused in a monastic, at that time a monastic cultivates the awakening factor of equanimity, at that time the awakening factor of equanimity comes to be accomplished in a monastic by cultivation.

(SN 54.13: so tathāsamāhitam cittam sādhukam ajjhupekkhitā hoti. yasmim samaye, ānanda, bhikkhu tathā samāhitam cittam sādhukam ajjhupekkhitā hoti, upekkhāsambojjhañgo tasmim samaye bhikkhuno āraddho hoti, upekkhāsambojjhañgam tasmim samaye bhikkhu bhāveti, upekkhāsambojjhango tasmim samaye bhikkhuno bhāvanāpāripūrim gacchati).

The awakening factor of concentration having been fulfilled, then greed and sadness cease and one attains balance and equipoise. At that time, one diligently cultivates the awakening factor of equanimity. Having cultivated the awakening factor of equanimity, the awakening factor of equanimity becomes fulfilled. (SĀ 810: 定覺分滿足已, 貪憂則滅, 得平等捨. 爾時 方便修捨覺分. 修捨覺分已, 捨覺分滿足).

The parallel versions offer what can be taken to be complementary perspectives, one being more concerned with the object of equanimity and the other more with its subjective stance. The more object-related perspective in the Pāli version indicates that equanimity arises once one "carefully oversees, without interfering, the mind that has become concentrated." The Chinese parallel in turn offers a spotlight on the subjective condition of equanimity, which is the inner mental balance that arises when "greed and sadness cease."

The parallel versions agree that the cultivation of these seven awakening factors builds on mindfulness as the first and foundational factor. It follows that here equanimity as an awakening factor is the result of the previous establishing of mindfulness as an awakening factor. Once the awakening factors have been aroused one-by-one, continuity of practice requires keeping all seven balanced. For achieving that, the recommendation is to give more emphasis to certain of these awakening factors, depending on the present condition of the mind. In case the mind is slightly sluggish, more emphasis should be given to the three awakening factors of investigation-of-states, energy, and joy. If the mind should rather be slightly agitated, more emphasis is to be given to the three awakening factors of tranquility, concentration, and equanimity. On all such occasions, however, mindfulness is required:
And I say that mindfulness is always useful.

(SN 46.53: satiñ ca khvāhaṃ ... sabbatthikam vadāmi).

The mindfulness awakening factor is always of use. (SĀ 714: 念覺分者一切兼助).

I say that mindfulness is to be cultivated at all times. (Up 7003: dran pa ni thams cad du 'gro ba'o zhes nga smra'o).

In this way, mindfulness provides the foundation for equanimity as an awakening factor to arise, and it performs the all-important monitoring function to alert the practitioner to what the present situation requires. In case the mind is slightly sluggish, an emphasis on equanimity (together with tranquility and concentration) would not be commendable. In this way, mindfulness emerges as the most important and foundational of the awakening factors.

Equanimity and mindfulness also feature in a simile that employs a chariot to illustrate various qualities required for progress along the noble eightfold path to awakening. The parts of the verse that illustrate mindfulness and equanimity are as follows:

Mindfulness is the watchful charioteer ...

Equanimity is the alignment of the pole.

(SN 45.4: sati ārakkhasārathi ... upekkhā

dhurasamādhi).

Mindfulness is the watchful charioteer,

Equanimity is the alignment that fits the pole.

(von Gabain 1954, p. 16: smṛti ärakșasārathi and

upekșā dhurisamyuktā samādhiś ca)

Being well protected by right mindfulness

Is like being a skilled charioteer.

Equanimity is the alignment for the functioning of the pole.

(SĀ 769: 正念善護持, 以爲善御者. 捨三昧爲轅).

The imagery of mindfulness as a watchful or skilled charioteer can be related to its monitoring function and to its resultant ability to provide a sense of direction. A charioteer needs to monitor the present traffic situation and maintain an overview of where the journey is meant to lead. Equanimity, representative of proper alignment (Cone 2010, p. 489), fulfills an important supportive role in the actual functioning of the chariot. At the same time, however, such a role is secondary in importance when compared to the charioteer. From this perspective, the simile can be taken to convey the primacy, in terms of import for actual practice, of mindfulness over equanimity.

As has become evident already in the passages surveyed above, there is considerable scope for the deployment of mindfulness even when equanimity is not present. Although the reference to the removal or overcoming of greed and sadness as a key dimension of the establishments of mindfulness 
allocates a significant role to equanimity, at the same time the Satipatthāna-sutta and its parallels include mindful recognition of unwholesome mental states, hindrances, and fetters in their purview. This becomes quite evident with the third establishment of mindfulness, just to present another example not yet taken up. The task here is to recognize with mindfulness that lust or anger is present in the mind:

One knows a mind with lust to be 'a mind with lust' ... [one knows a mind] with anger [to be 'a mind with anger'].

(MN 10: sarāgaṃ vā cittam, sarāgam cittan ti pajānāti ... sadosam).

The mind being with sensual desire, one knows, as it really is, that the mind is with sensual desire ... [the mind] being with anger [ one knows, as it really is, that the mind is with anger].

(MĀ 98: 有欲心, 知有欲心如真 ... 有恚).

The mind being with sensual craving, one then knows of oneself that the mind is with sensual craving ... the mind being with anger, one then knows of oneself that the mind is with anger.

(EĀ 12.1: 有愛欲心, 便自覺知有愛欲心 $\ldots$ 有値恚 心, 便自覺知有槇恚心).

The presence of these states implies that a strong type of reactivity is happening which is quite different from equanimity. Nevertheless, the act of mindful recognition, the ability to remain aware while lust and anger are present, can be remarkably transformative. Such practice will eventually issue in equanimity, in staying increasingly unaffected by greed and sadness, yet the potential of such freedom comes from being mindfully present when the mind is unbalanced. Understood in this way, mindfulness is indeed a watchful and skillful charioteer, enabling one to drive through the vicissitudes of life without accident.

Abbreviations AN: Anguttara-nikāya; DĀ: Dīrghaāgama (T 1); DN: Dīgha-nikāya; MĀ: Madhyama-āgama (T 26); MN: Majjhimanikāya; SĀ: Saṃyukta-āgama (T 99); SN: Saṃyutta-nikāya; T: Taishō edition; Up: Abhidharmakośopāyikā-țīkā; Vism: Visuddhimagga

Funding Open Access funding enabled and organized by Projekt DEAL.

\section{Declarations}

Ethical Approval This article does not contain any studies performed by the author with human participants or animals.

Conflict of Interest The author declares that there is no conflict of interest.
Open Access This article is licensed under a Creative Commons Attribution 4.0 International License, which permits use, sharing, adaptation, distribution and reproduction in any medium or format, as long as you give appropriate credit to the original author(s) and the source, provide a link to the Creative Commons licence, and indicate if changes were made. The images or other third party material in this article are included in the article's Creative Commons licence, unless indicated otherwise in a credit line to the material. If material is not included in the article's Creative Commons licence and your intended use is not permitted by statutory regulation or exceeds the permitted use, you will need to obtain permission directly from the copyright holder. To view a copy of this licence, visit http://creativecommons.org/licenses/by/4.0/.

\section{References}

Anālayo, Bh. (2008). Upekkhā. In W.G. Weeraratne (ed.), Encyclopaedia of Buddhism, volume 8, (pp. 422-449). Sri Lanka: Department of Buddhist Affairs.

Anālayo, Bh. (2011). A comparative study of the Majjhima-nikāya. Taipei: Dharma Drum Publishing Corporation.

Anālayo, Bh. (2013). Perspectives on Satipatthāna. Cambridge: Windhorse Publications.

Anālayo, Bh. (2014). The dawn of Abhidharma. Hamburg: Hamburg University Press.

Anālayo, Bh. (2014). The Hīnayāna fallacy. Journal of the Oxford Centre for Buddhist Studies, 6, 9-31.

Anālayo, Bh. (2015). Compassion and emptiness in early Buddhist meditation. Cambridge: Windhorse Publications.

Anālayo, Bh. (2017). What about neutral feelings? Insight Journal, 43, 1-10.

Anālayo, Bh. (2018). Satipatthāna meditation: A practice guide. Cambridge: Windhorse Publications.

Anālayo, Bh. (2019). Adding historical depth to definitions of mindfulness. Current Opinion in Psychology, Special Issue on Mindfulness, 28, 11-14. https://doi.org/10.1016/j.copsyc.2018.09.013

Anālayo, Bh. (2019). Immeasurable Meditations and Mindfulness. Mindfulness, 10(12), 2620-2628. https://doi.org/10.1007/ s12671-019-01237-0

Anālayo, Bh. (2019). The role of mindfulness in the cultivation of absorption. Mindfulness, 10(11), 2341-2351. https://doi.org/10. 1007/s12671-019-01206-7

Anālayo, Bh. (2019). A task for mindfulness: Facing climate change. Mindfulness, 10(9), 1926-1935. https://doi.org/10.1007/ s12671-019-01187-7

Anālayo, Bh. (2020). Mindfulness in early Buddhism, characteristics and functions. Cambridge: Windhorse Publications.

Anālayo, Bh. (2020). The Tevijjavacchagotta-sutta and the Anupadasutta in relation to the emergence of Abhidharma thought. Journal of Buddhist Studies, 17, 21-33.

Anālayo, Bh., \& Dhammadinnā, Bh. (2021). From compassion to selfcompassion: A text-historical perspective. Mindfulness, 12(6), 1350-1360. https://doi.org/10.1007/s12671-020-01575-4

Chan, C. H. Y., Chan, T. H. Y., Leung, P. P. Y., Brenner, M. J., Wong, V. P. Y., Leung, E. K. T., Wang, X., Lee, M. Y., Chan, J. S. M., \& Chan, C. L. W. (2014). Rethinking well-being in terms of affliction and equanimity: Development of a holistic well-being scale. Journal of Ethnic \& Cultural Diversity in Social Work, 23(3-4), 289-308. https://doi.org/10.1080/15313204.2014.932550

Cone, M. (2010). A dictionary of Pāli, part II, $g-n$. Oxford: Pali Text Society.

Desbordes, G., Gard, T., Hoge, E. A., Hölzel, B. K., Kerr, C., Lazar, S. W., Olendzki, A., \& Vago, D. R. (2015). Moving beyond mindfulness: Defining equanimity as an outcome measure in meditation 
and contemplative research. Mindfulness, 6(2), 356-372. https:// doi.org/10.1007/s12671-013-0269-8

Dreyfus, G. (2011). Is mindfulness present-centred and non-judgmental? A discussion of the cognitive dimensions of mindfulness. Contemporary Buddhism, 12(1), 41-54. https://doi.org/10.1080/ 14639947.2011.564815

Eberth, J., Sedlmeier, P., \& Schafer, T. (2019). PROMISE: A model of insight and equanimity as the key effects of mindfulness meditation. Frontiers in Psychology, 10(2389), 1-16. https://doi.org/10. 3389/fpsyg.2019.02389

Hadash, Y., Segev, N., Tanay, G., Goldstein, P., \& Bernstein, A. (2016). The decoupling model of equanimity: Theory, measurement, and test in a mindfulness intervention. Mindfulness, 7(5), 1214-1226. https://doi.org/10.1007/s12671-016-0564-2

Juneau, C., Pellerin, N., Elliott, T., Ricard, M., Shankland, R., \& Dambrun, M. (2019). Reliability and validity of an equanimity questionnaire: The two-factor equanimity scale (EQUA-S). PeerJ, 8(e9405), 1-19. https://doi.org/10.7717/peerj.9405

Juneau, C., Shankland, R., \& Dambrun, M. (2020). Trait and state equanimity: The effect of mindfulness-based meditation practice. Mindfulness, 11(7), 1802-1812. https://doi.org/10.1007/ s12671-020-01397-4

Juneau, C., Shankland, R., Knäuper, B., \& Dambrun, M. (2021). Mindfulness and equanimity moderate approach/avoidance motor responses. Cognition and Emotion, 1-14, https://doi.org/10.1080/ 02699931.2021 .1927674

Kabat-Zinn, J. (1994). Wherever you go, there you are: Mindfulness meditation in everyday life. New York: Hyperion Press.

Kabat-Zinn, J. (2011). Some reflections on the origins of MBSR, skillful means, and the trouble with maps. Contemporary Buddhism, 12(1), 281-306. https://doi.org/10.1080/14639947.2011. 564844

Lomas, T., Edginton, T., Cartwright, T., \& Ridge, D. (2015). Cultivating equanimity through mindfulness meditation: A mixed methods enquiry into the development of decentring capabilities in men. International Journal of Wellbeing, 5(3), 88-106. https://doi.org/ 10.5502/ijw.v5i3.7
Pagis, M. (2015). Evoking equanimity: Silent interaction rituals in Vipassana meditation retreats. Qualitative Sociology, 38(1), 39-56. https://doi.org/10.1007/s11133-014-9295-7

Rogers, H. T., Shires, A. G., \& Cayoun, B. A. (2021). Development and validation of the equanimity scale-16. Mindfulness, 12(1), 107-120. https://doi.org/10.1007/s12671-020-01503-6xx

Shoham, A., Hadash, Y., \& Bernstein, A. (2018). Examining the decoupling model of equanimity in mindfulness training: An intensive experience sampling study. Clinical Psychological Science, 6(5), 704-720. https://doi.org/10.1177/216770261877044

Stache-Rosen, V. (1968). Dogmatische Begriffsreihen im älteren Buddhismus II; das Sañītisūtra und sein Kommentar Sañgītiparyāya. Berlin: Akademie Verlag.

von Gabain, A. (1954). Türkische Turfan-Texte VIII. Berlin: Akademie Verlag.

Weber, J. (2017). Mindfulness is not enough: Why equanimity holds the key to compassion. Mindfulness \& Compassion, 2(2), 149158. https://doi.org/10.1016/j.mincom.2017.09.004

Weber, J., \& Lowe, M. (2021). Development and validation of the equanimity barriers scale [EBS]. Current Psychology, 40, 684698. https://doi.org/10.1007/s12144-018-9969-5

Weber, J. (2021). A systematic review of equanimity in mindfulness based interventions. Pastoral Psychology, 70, 151-165. https:// doi.org/10.1007/s11089-021-00945-6

Zeng, X., Oei, T. P. S., Ye, Y., \& Liu, X. (2015a). A critical analysis of the concepts and measurement of awareness and equanimity in Goenka's vipassana meditation. Journal of Religion and Health, 54(2), 399-412. https://doi.org/10.1007/s10943-013-9796-9

Zeng, X., Li, M., Zhang, B., \& Liu, X. (2015b). Revision of the Philadelphia mindfulness scale for measuring awareness and equanimity in Goenka's vipassana meditation with Chinese Buddhists. Journal of Religion and Health, 54(2), 623-637. https://doi.org/10.1007/s10943-014-9870-y

Publisher's Note Springer Nature remains neutral with regard to jurisdictional claims in published maps and institutional affiliations. 